\title{
Маслоделие в Западной Сибири в начале XX века: факторы развития, роль Союза сибирских маслодельных артелей
}

\begin{abstract}
Аннотачия: В статъе рассмотрен прочесс формирования предпринимательских структур в отрасли маслоделия в Западной Сибири - регионе, в котором эта отрасль пищевой промышленности стала развиватьсл с 90-х ге. ХІХ в., а в начале ХХ в. получила быстрое развитие, сравнялась по оббему с продукиией вологодских маслоделов и даже превысила его. Показана роль маслодельных артелей в производстве сибирского масла, деятельность съездов маслоделов и экспортеров масла в сфере сбыта сибирского масла и его экспорте. В работе используются методы компаративного и типологического анализа, приемы первичной статистической обработки, визуализаиии табличных данных. Детального рассмотрения деятельности съездов Союза сибирских маслодельных артелей пока проведено не было. Особый интерес представляет процесс вытеснения Союзом иностранных фирм - экспортеров сибирского масла, формирования более крупных артелей - производителей масла, согласования их интересов на договорной основе. Институщионализачия этого прочесса активизировалась в годы столыпинской реформы. Автор показывает, что развитие крупного артельного производства, создание Союза сибирских маслодельных артелей, деятельность съездов маслоэкспортеров и деятелей по молочному хозяйству способствовали гармонизачии интересов тысяч артелей, заводов по производству масла, повышению качества продукиии, содействовали возрастанию координаиионной роли этой корпоративной организачии, особенно в деле вывоза продукции сибирских маслоделов в районы основных рынков сбыта.
\end{abstract}

Annotation: This article examines the formation process of entrepreneurial structures in Western Siberian butter production - a region where this food industry sector started developing only in the 1890s, but then rapidly expanded at the beginning of the XXth century, so as to compare in volume to the butter production in the Vologda region, and even to surpass it. The author shows the significant role played by the butter-making cooperatives in the Siberian butter production, and the aims of the conventions of butter manufacturers and butter exporters in Siberian butter sales and exports. The research is based on the methods of comparative and typological analysis, primary statistical processing, and the visualization of tabular data. However, the author does not yet attempt a detail look into the activity of the conventions of the Union of Siberian butter-making cooperatives. Particular attention is given to the Union's displacement of foreign firms - exporters of Siberian butter, the formation of larger butter-making cooperatives - producers of butter, and their negotiations of interests on a contractual basis. The institutionalization of this process began during the years of Stolypin's reforms. The author demonstrates how the development of large cooperative production, the creation of the Union of Siberian butter-making cooperatives, the activity of the conventions of butter exporters and producers of the dairy industry, all contributed to the balancing of interests of thousands of cooperatives, butter-making factories, to the raised level of production quality, and to the increased coordination role of this cooperative organization, especially in the sphere of distribution of the Siberian butter-makers products to the main markets of consumption.

Ключевые слова: А. Н. Балакиин, Сбезд экспортеров масла, Союз маслодельных артелей, артели, производство сливочного масла, Западнал Сибирь, Кооперативные маслодельные товарищества, Ав. А. Калантар, артельнъе лавки, В. О. Сокульский.

Key Words: Western Siberia, butter production, cooperatives, Union butter-making cooperatives, Convention of butter exporters, A. N. Balakshin, cooperative butter-making association, Av. A. Kalantar, cooperative stores, V. O. Sokulsky. 


\section{Экономическая история, история предпринимательства}

DOI: $10.7256 / 2222-1972.2014 .3 .13770$

M

олочное хозяйство в пореформенной России являлось новой отраслью сельскохозяйственного производства, которая сформировалась в конце 60-х - начале 70-х гг. XIX в., а в середине 1880-х гг. быстро развивалась и в последующие три десятилетия достигла значительных успехов. Производство молочных продуктов в дореформенное время ограничивалось изготовлением топленого масла и - в небольших количествах сыра. Крупное производство сливочного масла формировалось с конца XIX в. в двух регионах в Вологодской губернии и в Западной Сибири.

В Западной Сибири маслоделие стало развиваться с 90-х гг. XIX в., чему способствовали существование крепких крестьянских хозяйств в Западной Сибири, более богатых естественных условий, открытие в 1894 г. Сибирской железной дороги, применение опыта организации артелей в Европейской России (особенно в Вологодской губернии).

В дореволюционных публикациях, посвященных истории маслоделия в Западной Сибири, затрагиваются вопросы возникновения данной отрасли промышленности, артельного производства, экспорта. Так, в работе «Экономическое исследование Сибири» ${ }^{1}$ рассмотрена история появления и развития маслоделия в Сибири, влияния этого процесса на разные стороны общественной жизни. Отмечена важность элементов самоорганизации в развитии маслоделия. В книге Н. В. Кулибиной ${ }^{2}$ исследуется история экспорта сливочного масла из Западной Сибири и Вологодской губернии на заграничные рынки. В период 1861-1880 гг. вывоз масла из России выражался лишь незначительными цифрами и не превышал в отдельные годы 200 тыс. пудов. В эти годы вывозилось исключительно топленое масло - как продукт более прочный и мало подвергающийся порче при перевозке и хранении. В конце 1880-х гг. в связи с интенсивным развитием маслоделия в северных районах (Вологодская, Ярославская губернии) и с переходом от выработки топленого масла на приготовление сливочного вывоз начал быстро возрастать и за пятилетие (18961900 гг.) составил уже в среднем в 655 тыс. пудов в год. Решающий импульс развитию вывоза дали возникновение выработки экспортного масла в Сибири и различные мероприятия, направ-

\footnotetext{
1 Экономическое исследование Сибири. Харьков, 1906.

2 Кулибина Н. В. Внешняя торговля маслом в связи с пересмотром торговых договоров. Петроград, 1915.
}

ленные на улучшение его транспортировки. Устройство вагонов-ледников, курсирование специальных ускоренных «масляных поездов» между станциями Сибирской железной дороги и портами Балтийского моря дали возможность, несмотря на дальние расстояния, эффективно сбывать сибирское масло на заграничные рынки, и это обстоятельство способствовало быстрому росту производства масла в Сибири. Вывоз масла из России пошел гигантскими шагами (с 1 млн. пудов в 1900 г. до 4 млн. пудов в 1914 г.). Большая часть вывозимого масла стала направляться на рынки Западной Европы (Германия, Англия, Дания).

В работах А. А. Мурашкинцева «О производстве и экспорте масла в Западной Сибири» ${ }^{3}$ и «Кооперативное маслоделие в Западной Сибири» ${ }^{4}$ исследуются вопросы производства масла (техника получения масла, содержания скота, устройство и состояние заводов) и его сбыта. Автор дает характеристику местного животноводства, отмечая, что необходимость в улучшении породы скота и его корма осознавалась более развитой частью крестьянского населения; так, выписывались коровы лучших пород. Дается типология предприятий по производству масла («заводов»), которые существовали в Западной Сибири в данный период, выделяются заводы паровые, конные, ручные. Преобладали ручные, на втором месте - конные, затем паровые. Такие заводы требовали немалых затрат на постройку и оборудование. В монографии Мурашкинцева уделяется внимание теме производства масла и его доставки. Выработанное масло доставлялось экспортным конторам по мере накопления. Конторы принимали масло по заранее установленной на целый год или девять месяцев цене. Если между сторонами происходил спор, относящийся к качеству масла, стороны обязаны были обратиться к местной арбитражной комиссии.

В контексте темы данного исследования представляет интерес серия работ В. К. Алексеевой, опубликованных в 1960-1970-х гг. В этих работах рассмотрена история кооперативного движения в конце XIX - начале XX вв., одним из проявлений которого были маслодельческие артели ${ }^{5}$. Первый кооператив возник в 1896 г.

\footnotetext{
3 Мурашкинцев А. А. О производстве и экспорте масла в Западной Сибири. СПб., 1902.

4 Он же. Кооперативное маслоделие в Западной Сибири. СПб., 1902.

5 Алексеева В. К. К вопросу о развитии маслодельческой ко-
} 


\section{Исторический журнал: научные исследования № 3 (21) • 2014}

DOI: $10.7256 / 2222-1972.2014 .3 .13770$

в Тобольской губернии, к 1914-1916 гг. было кооперировано около $70 \%$ всех маслозаводов. В условиях острой конкурентной борьбы положение кооперативов не было стабильным, и многие из них закрывались. Появилась потребность в укреплении маслодельных артелей, и в 1907 г. 12 артелей Тобольской губернии объединились в Союз сибирских маслодельных артелей. Задачи союза состояли в выработке стандартных правил качественного производства масла и урегулировании вопросов экспорта продукции на зарубежный рынок. Анализируя торговлю сибирским маслом накануне Первой мировой войны, В. К. Алексеева отмечает одну из главных причин, стимулировавших производство и сбыт сливочного масла, - увеличение потребности в продуктах сельского хозяйства на европейских рынках, обусловленное ростом промышленности и городов, сокращением сельскохозяйственного сектора ${ }^{6}$. Экспорт сибирского масла в начале развития отрасли находился в зависимости от иностранных фирм-посредников. Попытка самостоятельного выхода на иностранный рынок была предпринята Организацией по устройству кооперативных маслодельных товариществ, Coюзом сибирских маслодельных артелей и «Сибирским товариществом».

Еще один сюжет в работах В. К. Алексеевой связан с анализом процесса превращения маслоделия в ведущую отрасль сельского хозяйства Сибири в конце XIX - начале XX вв. ${ }^{7}$ Автор характеризует Сибирь данного периода как регион с огромными потенциальными возможностями (не вполне реализованными) для развития сельского хозяйства и промышленности. Маслоделие определило характер специализации сибирского сельского хозяйства в начале XX в. и превратило Сибирь в крупный центр скотоводства и молочного хозяйства. Алексеева пишет, что основные преимущества молочного направления сельского хозяйства перед остальными отраслями состояли в большей интенсификации сельского хозяйства, повышении уровня товарности за счет экспорта продукции. Рассматривая технологические аспекты производства

операции в Сибири // Бахрушинские чтения 1971 г. Выпуск 7. Новосибирск, 1972. С. 77-84.

6 Она же. Торговля сибирским маслом накануне Первой мировой войны. Исторические аспекты экономического, культурного и социального развития Сибири. Часть 2. Новосибирск, 1978. С. 41-46.

7 Она же. Превращение маслоделия в ведущую отрасль сельского хозяйства Сибири в конце XIX - начале XX вв. // Бахрушинские чтения 1974 г. Новосибирск, 1974. С. 134-139. масла в Сибири ${ }^{8}$, Алексеева отмечает, что значительную роль в развитии местного маслоделия сыграло появление сепаратора. С этого момента маслоделие выделяется в самостоятельную отрасль сельского хозяйства. Исследователь говорит о проблемах, связанных с развитием артельного производства. Крестьяне нередко не понимали выгоды от производства, существовали разные предрассудки. Успешное становление артельного маслоделия повлекло за собой острую конкуренцию, частные предприниматели препятствовали организации артелей (повышали плату за молоко, иногда поджигали заводы). Автор показывает и положительные стороны артельной формы организации данной отрасли - артельное производство для крестьян было более выгодным и удобным, чем домашнее или частный завод. Прибыль делилась между крестьянами пропорционально количеству коров, заводы были оснащены усовершенствованным оборудованием, соблюдались санитарные условия. Появление железной дороги, соединявшей Сибирь с Европейской Россией, способствовало бурному развитию артельного маслоделия; обилие местных лугов, разведение продуктивных пород скота также сыграли свою положительную роль. С формированием Союза сибирских маслодельных артелей значительная часть производства и сбыта сконцентрировалась в руках этой организации.

Однако детального рассмотрения ее деятельности, и особенно съездов Союза сибирских маслодельных артелей, пока проведено не было. Особый интерес представляет процесс вытеснения Союзом иностранных фирм - экспортеров сибирского масла, формирования более крупных артелей - производителей масла, согласования их интересов на договорной основе. Институционализация этого процесса активизировалась в годы столыпинской реформы. Эти аспекты и находятся в центре внимания данной работы.

\section{Становление и развитие маслоделия в Сибири: роль маслодельных артелей}

В начале XIX в. в Сибири началась выработка топленого масла, которого производилось ежегодно в среднем 1 млн. пудов. Все производство находилось преимущественно в руках женского

8 Она же. Артельное маслоделие в Сибири // Вопросы истории социально-экономической и культурной жизни Сибири и Дальнего Востока. Выпуск 2. Новосибирск, 1968. С. 78-92. 


\section{Экономическая история, история предпринимательства}

населения 9 . Выработанное масло поступало к местным скупщикам, а через местные ярмарки свозилось в Петербург, Москву, Одессу и отчасти в Турцию. Первую маслодельню для экспорта соленого масла открыл в 1893 г. в Курганском уезде купец Вальков, начавший покупать молоко у местных крестьян. Выгода нового дела привлекла многих предпринимателей из местных купцов, мещан, зажиточных крестьян ${ }^{10}$. Стали образовываться товарищества из крестьян, возникать общественные (сельские общества) и артельные маслодельни.

Маслодельные артели возникли в Западной Сибири в 1890-х гг. Видную роль в их появлении сыграл старший инструктор по молочному хозяйству В. О. Сокульский, который открыл первую артельную маслодельню в 1896 г. в Ялуторовском уезде $\mathrm{e}^{11}$. Создание артелей проходило трудно - организаторы нередко встречали упорное сопротивление со стороны населения. Большинство крестьян не могли сразу осмыслить новые явления и видели в артелях вредные изменения. Происходивший в этот период переход от натурального к товарному хозяйству (отчасти как следствие и появления маслоделия) сопровождался трудностями, крестьянам было сложно освоиться в новых условиях. Также влияли общие условия крестьянского хозяйства - с увеличением числа коров пастбищ не хватало, а их расширение угрожало господствующей системе полеводства (трехполье и переложный способ пользования землей). К тому же большинство крестьян было подвержено суевериям, и нередки были случаи уничтожения сепараторов и других машин. Только с течением времени (с 1901 г. - см. рис. 1), после наглядного ознакомления с выгодой создания артелей, крестьяне убедились в пользе нарождающегося дела.

Как видно из графика, рост числа маслодельных артелей шел в Западной Сибири быстрыми темпами, и, несмотря на все препятствия, к 1907 г. было открыто 700 артелей. Причины столь быстрого роста были в выгодности этой отрасли молочного хозяйства при развитом в Сибири скотоводстве, хорошем качестве молока сибирских коров, значительном спросе на масло ${ }^{12}$. Первоначально началась эксплуа-

\footnotetext{
9 Мурашкинцев А. А. О производстве и сбыте экспортного масла в Западной Сибири... С. 3.

10 Там же.

11 Вестник кооперации. Кн. 1. СПб., 1909. С. 16.

12 Мурашкинцев А. А. О производстве и сбыте экспортного масла в Западной Сибири... С. 7.
}

DOI: $10.7256 / 2222-1972.2014 .3 .13770$

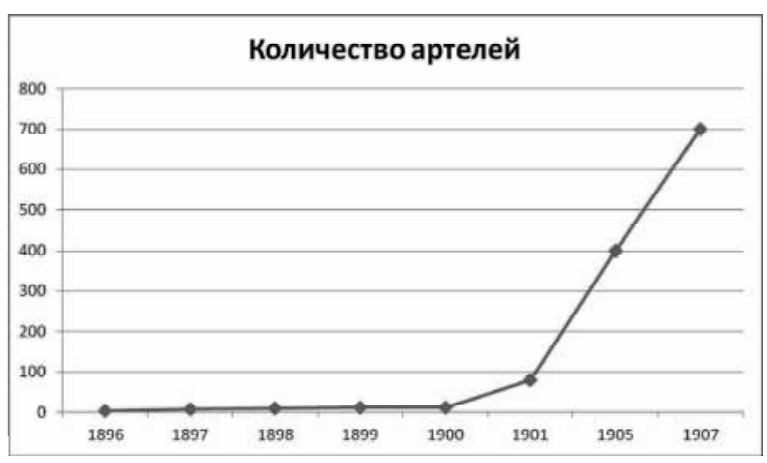

Рис. 1. Рост числа маслодельных артелей в Западной Сибири в 1896-1907 гг.

Источник: Отчет Союза сибирских маслодельных артелей за 1913 г. Курган, 1914. С. 142.

тация отдельных крестьянских дворов частными предпринимателями-маслоделами, частные маслодельные заводы стали разрастаться, что не могло привести к улучшению качества масла - возрастающая выгода маслоделия зачастую привлекала частных предпринимателей без технических знаний, достаточного капитала, добросовестности и дальновидности. Это стало одной из важных причин перехода к артельному производству. Всего к 1900 г. в Западной Сибири было организовано 1107 маслодельных заводов, которые неравномерно распределялись по губерниям (см. табл. 1).

Таблииа 1

Численность маслодельных заводов по губерниям к 1900 г.

\begin{tabular}{|c|c|}
\hline Губернии & $\begin{array}{c}\text { Всего маслодельных } \\
\text { заводов (1894-1900 гг.) }\end{array}$ \\
\hline Оренбургская & 43 \\
\hline Тобольская & 362 \\
\hline Томская & 246 \\
\hline Акмолинская & 40 \\
\hline
\end{tabular}

Источник: Мурашкинцев А. А. О производстве и сбыте экспортного масла в Западной Сибири (отчет по командировке в Тобольской губернии). СПб., 1902. С. 6.

Из данной таблицы видно, что большинство заводов по производству сливочного масла находились в Тобольской и Томской губерниях.

Возникнув в 1893 г. около города Кургана, производство сливочного масла распространилось к востоку (Алтай), западу (Челябинский и Шадринский уезды), северу (до Тобольского уезда) и югу (в Акмолинской степи).

В первый период (1896-1901 гг.) артельное движение претерпело ряд неудач из-за недостатка опытности, неумения поставить технически 


\section{Исторический журнал: научные исследования № 3 (21) • 2014}

DOI: $10.7256 / 2222-1972.2014 .3 .13770$

дело. Однако скоро оно стало развиваться быстрыми темпами, вытесняя частные заводы ${ }^{13}$.

Во второй период (с 1901 г.) артели начали создаваться на основе договора и некоторой унификации производства. Крупную роль в этом сыграла организация по устройству кооперативных маслодельных товариществ в Западной Сибири (1902-1907 гг.), во главе которой встал А. Н. Балакшин ${ }^{14}$. Деятельность организации выражалась в составлении договора при образовании товариществ, указании необходимого инвентаря для оборудования маслодельных заводов, составлении планов заводов, рекомендации мастеров, наблюдении за техникой, проверке отчетности. Организация работала пять лет и к концу своей деятельности смогла открыть полторы сотни артельных заводов. Заслуга ее заключается в широкой и открытой пропаганде, умело составленных отчетах. Эта организация сделала первый шаг на пути централизации регулирования и контроля над маслоделием Западной Сибири и значительно увеличила его производительность.

Основными статьями артельного договора были ${ }^{15}$ : для устройства завода ее члены обязывались внести в общую кассу определенную сумму с коровы на постройку и приспособление завода; членами считались домохозяева, внесшие сумму и доставлявшие молоко на завод; каждый из членов состоял владельцем завода в доле; каждый новый член должен был внести в артель вступительный взнос; члены артели обязывались не продавать молоко на другие заводы; в случае смерти артельщика права переходили родственникам; молоко обязывали сдавать чистое, не разбавленное в луженых ведрах; делами артели управлял совет или собрание уполномоченных, избираемых ежегодно; для ведения дел по операциям завода и расчета с работниками избирался староста; для контроля старосты избирались три учетчика.

Артель выбирала доверенного, и ему поручалось ведение всех операций. Для контроля доверенного избирались учетчики, производившие учет всех операций. Делами артели управляло общее собрание всех членов, каждый из которых имел одинаковый голос независимо от числа коров и сделанных взносов. Долги погашались постепенными отчислениями. Новые члены принимались в артель при условии допол-

\footnotetext{
13 Там же.

14 Вестник кооперации. Кн. 4. СПб., 1913. С. 28.

15 Там же.
}

нительных взносов ${ }^{16}$ : существовала разница при расчете за молоко в зависимости от времени нахождения в артели, неполучения добавочных выдач из прибылей. Все постановления артели заносились в книгу мастером артельного дела. Приносимое молоко и выход масла записывались в особые книжки, которые находились в ведении приносивших. Расплата за молоко производилась ежемесячно, предварительная сумма проверялась учетчиком, выдача происходила по талонам. Поставка масла экспортным конторам была по особым накладным, подписываемым уполномоченными экспортера.

Молоко доставлялось крестьянами на маслодельни в железных и луженых ведрах и взвешивалось. Обезжиривание поступившего молока производилось в сепараторе. Отделенные сливки поступали в квасильное отделение, где подогревались и заквашивались специальной закваской, качество которой являлось решающим фактором для качества будущего масла. Из-за важности процесса старались подбирать хорошо проветриваемые и сухие помещения, а сквашивание производили в дубовых кадках в две смены. После окончания данного процесса сливки доводились до благоприятной для сбивания масла температуры и помещались в маслобойки. Потом масло промывалось в холодной воде и выкладывалось в корыта. Затем оно помещалось на маслообработник, который отжимал масло. После первой отжимки масло взвешивалось и смешивалось с солью. Для посолки употреблялась крымская соль, хорошо просушенная, мелко растертая и просеянная. Затем масло оставлялось в покое и отжималось еще два раза. По окончании отжима масло набивалось в подготовленный бочонок, который взвешивался и помещался в ледник.

Необходимые машины и принадлежности для производства масла артельщики получали от экспортных контор (братья Бландовы, фирма «Работник», В. Н. Верещагин ${ }^{17}$, представители иностранных заводов) $)^{18}$. Маслобойки употреблялись вертикальные - система Лефельдта или голштинская. Маслообработники - систем Листера, Альфа. Рабочий персонал маслоделен состоял из мастера, его помощника и поденных

\footnotetext{
16 Там же. С. 33.

17 Особую роль В. Н. Верещагина в этом процессе отмечает А. В. Гутерц в недавно вышедшей книге. См.: Гутерц А. В. Николай Верещагин. На благо Отечества. Вологда, 2011.

18 Мурашкинцев А. А. Кооперативное маслоделие в Западной Сибири... С. 5.
} 


\section{Экономическая история, история предпринимательства}

рабочих, нанимавшихся для вращения ручных сепараторов. Мастерами были выпускники местных маслодельных курсов. Мастера получали 240-600 руб. в год при готовой квартире, отоплении, освещении и бесплатном пользовании маслом и молоком. Помощникам платилось 10-15 руб. в месяц, наем рабочих производился по стандартной плате.

Однако, несмотря на все усилия организации по устройству кооперативных маслоделен, в маслодельном производстве все еще оставался ряд недостатков - в первую очередь в санитарногигиеническом плане ${ }^{19}$. В устройстве заводов наблюдалось большое разнообразие: существовали заводы с обширными, чистыми помещениями и заводы в избах или банях. На одном из осмотренных заводов маслодельня помещалась в избе с двумя комнатами, при которой находился ледник. Полы были дощатые, со щелями, на дверях оказалась плесень. Заводы простейшего устройства требовали больших затрат на постройку и оборудование. Для организации работы маслодельни пришлось изыскивать разнообразные источники: деньги из общественных сумм, займы у частных лиц или у зажиточных домохозяев, промышленные ссуды и случайные поступления. Ав. А. Калантар после посещения ряда заводов писал, что на заводах плохие подвалы для хранения масла, из технических недочетов отмечалось отсутствие пастеризации (предварительного подогревания молока). Масло отличалось невысоким качеством, и на заграничных рынках цена на него была значительно ниже финского и датского масел. На пятом конкурсе масла в 1908 г. из 24 образцов только одна артель получила малую серебряную медаль и три - похвальные листы за удовлетворительное качество масла ${ }^{20}$.

В 1908 г. возник Союз сибирских маслодельных артелей, созданный А. Н. Балакшиным, главной целью которого было искоренение посредничества иностранцев-экспортеров, которые забрали весь заграничный рынок вывоза масла из Сибири ${ }^{21}$. Выход виделся один - взятие артельщиками под контроль сбыта за границу своей продукции. К апрелю 1908 г. в Союз входило 60 артелей с производством 150000 пудов масла, в октябре уже было 68 артелей. За первые три месяца через конторы Союза прошли 3523 бочки, 12203 пуда масла.

\footnotetext{
19 Там же.

20 Там же. С. 7.

21 Там же.
}

DOI: $10.7256 / 2222-1972.2014 .3 .13770$

По данным Союза сибирских маслодельных артелей, за 1911 г. было получены следующие объемы масла (см. табл. 2).

Количество масла, полученное Таблича 2

\section{Союзом сибирских маслодельных артелей в 1911-1913 гг.}

1911 r.

\begin{tabular}{|l|c|}
\hline \multicolumn{1}{|c|}{ Район } & Количество масла (пуд.) \\
\hline Курганский & 81238 \\
\hline Челябинский & 12961 \\
\hline Барнаульский & 19757 \\
\hline Петропавловский & 15333 \\
\hline Бийский & 52121 \\
\hline
\end{tabular}

Источник: Отчет Союза сибирских маслодельных артелей за 1911 г. Курган, 1912. С. 11.

1912 r.

\begin{tabular}{|l|c|}
\hline \multicolumn{1}{|c|}{ Район } & Количество масла (пуд.) \\
\hline Курганский & 145854 \\
\hline Челябинский & 35782 \\
\hline Ялуторовский & 1620 \\
\hline Петропавловский & 29573 \\
\hline Барнаульский & 53382 \\
\hline Каменский & 111967 \\
\hline Бийский & 7267 \\
\hline
\end{tabular}

Источник: Отчет Союза сибирских маслодельных артелей за 1912 г. Курган, 1913. С. 5-15.

1913 г.

\begin{tabular}{|l|c|}
\hline \multicolumn{1}{|c|}{ Район } & Количество масла (пуд.) \\
\hline Курганский & 1000196 \\
\hline Челябинский & 32397 \\
\hline Троицкий & 20302 \\
\hline Ялуторовский & 34191 \\
\hline Петропавловский & 40643 \\
\hline Бийский & 75397 \\
\hline Барнаульский & 109829 \\
\hline
\end{tabular}

Источник: Отчет Союза сибирских маслодельных артелей за 1913 г. Курган, 1914. С. 21-25.

Из данных табл. 2 можно увидеть, что в 1911-1913 гг. наибольшее количество сливочного масла поступало в Союз из Курганского района (около 2000000 пудов).

Все артели, входящие в состав Сибирского союза, были основаны по договору, главными пунктами которого являлись следующие 22 : по всем обязательствам Союзу артель отвечала взаимным поручительством; все дела велись по обоюдному согласию к взаимной пользе на основании постановлений артели; для ведения дел из артельной среды избирался доверенный; ар-

22 Вестник кооперации. Кн. 1... С. 15. 


\section{Исторический журнал: научные исследования № 3 (21) • 2014}

DOI: $10.7256 / 2222-1972.2014 .3 .13770$

тель избирала учетчиков; мастера нанимались артельным сходом; права, обязанности, вознаграждение всех избираемых и нанимаемых лиц определялись артельным сходом; в случае умышленной порчи молока должен был выплачиваться штраф; со всех проживающих в местности завода, желавших вступить в артель, бралась вступительная плата с каждой имеющейся коровы; в случае сдачи молока на другой завод выплачивалась в пользу артели неустойка; выход из артели был допустим при перемене места жительства; артель могла вести другие торговые дела.

Отношения между правлением Союза и артелями были закреплены постановлениями ${ }^{23}$ : союзные артели должны были кредитоваться только у Союза, при выходе артели из Союза взыскивалась неустойка, члены Союза обязаны были вести через Союз все свои коммерческие операции, союзные заводы должны были приготовлять масло согласно указаниям Союза, определение цен на масло на местных рынках производилось в артелях.

Таким образом достигались еще большая централизация и контроль Союза над маслодельным производством.

Существенную роль в росте маслодельных артелей играло устройство артельных лавок. Правление Союза пришло к выводу, что объединение сибирского крестьянина на производстве только половина дела, необходимо было снабдить его припасами, т. е. дать возможность покупать на выручку от молока необходимые продукты, но не было достаточно времени, свободных средств, кредита, связей с фабрикантами, чтобы организовать сразу артельные лавки при маслодельнях. В 1910 г. при Курганской конторе был открыт оптовый склад бакалеи, посуды и т. д. Союз добавлял к покупной цене товара примерно 5\% (в частной лавке 20-25\%). Артельная лавка обслуживала сразу несколько деревень, связанных с артельным заводом. Лавки должны были организовываться по особым договорам, члены лавки отвечали за все кредиты своим имуществом, лавки обязаны были покупать все товары через Союз, покупка их артельщиками являлась обязательной.

Союзу активно противостояли частные заводчики, мелкие лавочники и скупщики, которые вытеснялись из деревни ${ }^{24}$. Зажиточные крестьяне называли членов Союза мошенника-

\footnotetext{
23 Там же. С. 17.
}

24 Там же. С. 20. ми, устраивалась травля артельщиков, организаторов лавки, зернохранилища, кредитного товарищества. Создавалась и распространялась литература, обличающая Союз в фальсификации отчетов, в неумелости и лишении населения прибылей, которые они могли бы получать, сдавая масло әкспортным конторам («Хрестоматия артельщиков», «Справочный листок», перепечатки статей из «Молочного хозяйства») $)^{25}$.

Особую роль в координации производства масла и его экспорта играли съезды сибирских маслоделов и маслоэкспортеров. Эта организационная форма в наибольшей мере характеризует специфику маслоделия в Сибири в сравнении с вологодским маслоделием.

\section{Съезды Союза сибирских маслодельных артелей и их роль в производстве и экспорте сибирского масла}

Еще до возникновения Союза сибирских маслодельных артелей для координирования предприятий данной отрасли промышленности - и в первую очередь для развития и контроля над продажами масла в России и за границей - начали собираться съезды маслоделов и маслоэкспортеров. Съезды Союза сибирских маслодельных артелей собирались с 1907 г. ежегодно, на них присутствовали ответственные представители различных ведомств, маслоделы, экспортеры. На съездах обсуждались основные вопросы производства и продажи сливочного масла (отчеты о вывозе масла за прошедшее время - вывезено в действительности, предположено к вывозу, количество вагонов для перевозки, скорость и время в пути, составление плана на будущий год (по районам, пунктам назначения), качество масла, состояние маслодельных заводов).

Основными задачами съездов являлись ${ }^{26}$ : выяснение нужд местного производства, торговли и транспорта сливочного масла, выработка мер к удовлетворению данных нужд, рассмотрение статистических данных о производительности заводов и о предполагаемом вывозе. Рассмотрим деятельность съездов Союза сибирских маслодельных артелей, обратившись к информативному изданию - «Труды Съезда маслоделов и экспортеров масла Западной Сибири». Мы рассмотрим съезды, проходившие в 1907, 1909, 1911,1913 гг.

\footnotetext{
25 Там же. С. 21.

26 Труды Съезда маслоделов и экспортеров масла Западной Сибири. Омск, 1908. С. 119.
} 


\section{Экономическая история, история предпринимательства}

Первый Съезд маслоделов и экспортеров прошел с 8 по 12 октября 1907 г. в Омске ${ }^{27}$. Председателем съезда был избран Ав. А. Калантар. Съезду была представлена ведомость о процентном приросте отправки масла на запад с 1903 по 1907 гг. (см. диаграмму, рис. 2).

Из данной диаграммы видно, что наибольший прирост вывоза масла за 1903-1907 гг. падает на Петропавловский район (31\%).

В 1906 г. с 1 января по 1 октября вывезено 2620173 пудов, в 1907 г. - 3161749 пудов. Исходя из этих данных вывоз в предыдущую кампанию увеличился на 541576 пудов (20,6\%). В 1906 г. с 1 апреля по 1 октября вывезено 2251249 пудов, в 1907 г. - 2736195 пудов. Увеличение за этот период выразилось в 484946 пудах (21,5\%).

Сравнительные данные о запланированном и действительно вывезенном количестве масла по месяцам в 1907 г. приводятся в табл. 3.

Таблииа 3

Вывоз масла по районам в 1907 г.

\begin{tabular}{|l|c|c|}
\hline \multicolumn{1}{|c|}{ Район } & Назначено к вывозу & Вывезено \\
\hline Курганский & 692000 & 717754 \\
\hline Петропавловский & 182000 & 190214 \\
\hline Омский & 759000 & 766894 \\
\hline Каинский & 173000 & 154205 \\
\hline Барнаульский & 909000 & 907128 \\
\hline
\end{tabular}

Источник: Труды Съезда маслоделов и әкспортеров масла Западной Сибири 8-12 окт. 1907 г. Омск, 1908. С. 66.

Как видно из таблицы, по трем районам было вывезено больше плановых объемов масла (Курганский $+3 \%$, Петропавловский $+4,5 \%$, Омский $+1 \%)$.

Табл. 4 показывает распределение перевозок масла в 1907 г. по пунктам назначения.

Таблииа 4

Вывоз масла по пунктам назначения в 1907 г. (пуд.)

\begin{tabular}{|l|c|}
\hline \multicolumn{1}{|c|}{ Пункты назначения } & Всего \\
\hline Рига & 1023045 \\
\hline Виндава & 1358251 \\
\hline Новый Порт & 528860 \\
\hline Петербург & 194427 \\
\hline Ревель & 559 \\
\hline Москва & 6199 \\
\hline Другие назначения & 50408 \\
\hline
\end{tabular}

Источник: Труды Съезда маслоделов и экспортеров масла Западной Сибири 8-12 окт. 1907 г. Омск, 1908. С. 69.

Исходя из таблицы 4 основными пунктами назначения в 1907 г. были балтийские порты -

27 Там же. С. 1.
DOI: $10.7256 / 2222-1972.2014 .3 .13770$

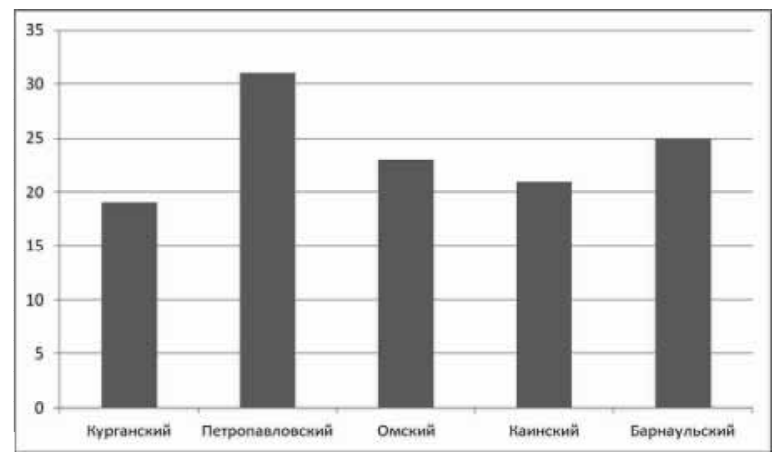

Рис. 2. Средний процент прироста вывоза масла по районам за 1903-1907 гг.

Источник: Труды Съезда маслоделов и экспортеров масла Западной Сибири 8-12 окт. 1907 г. Омск, 1908. С. 65.

Виндава и Рига. Всего в кампанию 1907 г. было вывезено 3161749 пудов масла, прирост определился в $19 \%$. В перевозке масла были задействованы 1370 вагонов.

На основе данных за несколько лет на заседании съезда определили количество масла к вывозу в 1908 г. - 4000000 пудов (принималось во внимание увеличение не выше $15 \%$ ), которое распределилось по районам: Курганский (966 000 пудов), Петропавловский (386 000 пудов), Омский (1 151000 пудов), Каинский (227 000 пудов), Барнаульский (1270 000 пудов $)^{28}$.

По вопросу об издании обязательных постановлений для маслодельных заводов в целях урегулирования производства масла съезд постановил ${ }^{29}$ : ходатайствовать перед Главным управлением землеустройства и земледелия о скорейшим утверждении и проведении в жизнь следующих выработанных правил. Лица, устраивающие маслодельные заводы, должны оповещать инструктора молочного хозяйства, помещение для маслодельного завода (здание) должно состоять из двух комнат, в полу не должно быть щелей, в помещении рабочим спать запрещалось. Съездом были приняты также постановления по разным вопросам: ходатайствовать об увеличении числа инструкторов и платы им, назначении особой комиссии для выяснения обстоятельств хищения масла в пути ${ }^{30}$.

В 1909 г. заседание Съезда маслоэкспортеров и маслоделов состоялось 10-13 декабря в Омске $^{31}$. Председателем съезда был избран началь-

\footnotetext{
28 Там же. С. 71.

29 Там же. С. 76.

30 Там же. С. 78.

31 Журналы заседаний Съезда маслоэкспортеров и маслоделов 10-13 декабря 1909 г. Омск, 1910. С. 2.
} 


\section{Исторический журнал: научные исследования № 3 (21) • 2014}

DOI: $10.7256 / 2222-1972.2014 .3 .13770$

ник коммерческой части Сибирской железной дороги Л. Б. Ленцер. В программу съезда были включены вопросы ${ }^{32}$ о недочетах транспорта для экспорта масла (невывезенное масло на станции Новониколаевской Сибирской железной дороги, недостаток запаса льда в станционных ледниках), о выработке заданий масляной кампании на 1910 г. (выяснение количества масла, отправленного из всего района, по отдельным станциям и пунктам в 1909 г., определение общего количества масла, ожидаемого к вывозу в 1910 г,, распределение отправки по отдельным станциям, потребное число вагонов-ледников, устройство и увеличение маслохранилищ, проводники поездов и их рапорты), об улучшении постановки масляного дела, препятствующих этому причинах и разработке мер к их устранению (доклады о деятельности инструкторов, о мерах к улучшению качества масла, устройство курсов маслоделов).

Для перевозки произведенного количества масла число вагонов-ледников определилось в 5658 вагонов. В 1909 г. в распоряжении Сибирской дороги имелось 1537 вагонов-ледников. Опираясь на опытные данные прошлых лет, для одного поезда Западного направления требовалось 129 вагонов-ледников и 108 вагонов-ледников для поезда Северного направления (средний состав поезда - 25 вагонов-ледников). В связи со слабым подвозом масла вместо предположенных к отправлению 5658 вагонов-ледников в действительности было отправлено 5110.

В 1909 г. экспорт масла превысил размер перевозки в кампанию 1907 и 1908 гг. ${ }^{33}$ Недовывезено против задания $6,9 \%$. За весь год было вывезено на запад 3539749 пудов, а в летнюю кампанию - 2980878 пудов (84\% от годовой отправки). Вывоз масла в летнюю кампанию (апрель-октябрь) по районам распределился таким образом.

Таблииа 5

Вывоз сибирского масла по районам в 1909 г.

\begin{tabular}{|l|c|c|}
\hline \multicolumn{1}{|c|}{ Район } & $\begin{array}{c}\text { Предполо- } \\
\text { женок вывозу } \\
\text { (пуд.) }\end{array}$ & $\begin{array}{c}\text { Вывезено } \\
\text { в действитель- } \\
\text { ности (пуд.) }\end{array}$ \\
\hline Курганский & 832000 & 769971 \\
\hline Петропавловский & 221000 & 216983 \\
\hline Омский & 831000 & 855287 \\
\hline Каинский & 192000 & 127691 \\
\hline Барнаульский & 1206000 & 1010946 \\
\hline
\end{tabular}

Источник: Журналы заседаний Съезда маслоэкспортеров и маслоделов 10-13 дек. 1909 г. Омск, 1910. С. 3.

\footnotetext{
32 Там же.

33 Там же. С. 4.
}

Наибольшее количество недовывоза против предположений относится к Каинскому $(33,48 \%)$ и Барнаульскому $(16,7 \%)$ районам, а Омский район $(2,92 \%)$ дал превышение. По месяцам наибольший недовывоз падает на апрель $(31,08 \%)$ и май $(23,66)$, июнь $(16,45 \%)$ дал превышение ${ }^{34}$. Причинами невыполнения задания являлись неблагоприятные условия для крестьянского хозяйства в этом году. Вывоз масла на восток оказался выше прошлогоднего 24166 пудов (12 703 пудов в 1908 г.).

В кампанию 1909 г. каждый масляный поезд сопровождался двумя масляными агентами, в их обязанности входило наблюдение за своевременным следованием масляного поезда и исправным пополнением вагонов-ледников ${ }^{35}$. Всего было сопровождено 146 поездов.

Общее количество ожидаемого к вывозу масла в кампанию 1910 г. съезд определил в 3292800 пудов. Распределение данного количества масла по районам дается в табл. 6.

Таблича 6

\section{Предполагаемое количество масла} к вывозу в 1910 г.

\begin{tabular}{|l|c|}
\hline \multicolumn{1}{|c|}{ Район } & Количество масла (пуд.) \\
\hline Барнаульский & 12004000 \\
\hline Каинский & 162300 \\
\hline Омский & 905200 \\
\hline Петропавловский & 222100 \\
\hline Курганский & 802810 \\
\hline
\end{tabular}

Источник: Журналы заседаний Съезда маслоэкспортеров и маслоделов 10-13 дек. 1909 г. Омск, 1910. С. 18.

Исходя из данной таблицы наибольший вывоз сливочного масла в кампанию 1910 г. планировался из Барнаульского района.

Распределение перевозок по направлениям было обозначено: северное направление 2183000 пудов, западное направление - 1109800 пудов. Для кампании 1910 г. определили подъемную силу вагона-ледника в 590 пудов и соответственно подсчитали количество вагонов-ледников, которое потребуется в 1910 г., - 5581.

На заседании съезда обсуждался вопрос о мерах улучшения качества экспортного масла ${ }^{36}$. Причины, препятствующие улучшению качества масла, заключались в малочисленности иностранного персонала, отсутствии правильной расценки на масло (первый сорт масла от-

\footnotetext{
34 Там же. С. 5.

35 Там же. С. 10.

36 Там же. С. 49.
} 


\section{Экономическая история, история предпринимательства}

DOI: $10.7256 / 2222-1972.2014 .3 .13770$

личался от других сортов всего на 20-25 коп., поэтому маслоделам не было выгоды производить лучшие сорта масла), а также в том, что значительная часть заводов находилась в плачевном состоянии (земляной пол, самоучек - 67\%, мастеров, окончивших молочную школу, - 33\%). Для улучшения качества было принято решение распространить популярные брошюры по маслоделию, обязать заводы к маркировке своего масла и принимать на заводы в основном тех, кто получил профильное образование. Съезд постановил возбудить ходатайство перед Главным управлением землеустройства о том, чтобы оно разрешило и содействовало организации курсов молочного хозяйства и изданию популярных брошюр по маслоделию, и ходатайствовать перед надлежащими властями, чтобы в программу низших сельских школ было включено преподавание сведений по маслоделию и молочному хозяйству. Также съезд поручил разработку правил содержания масляных заводов (определение типов заводов, указания санитарного, технического и практического характера) Масляной комиссии при Омской бирже.

Съезд 1911 г. проходил в Омске 22-23 января в помещении Омской биржи ${ }^{37}$. На заседании присутствовали 15 членов, председателем был избран Л. Б. Ленцер. В программу совещания входили вопросы распределения вагонов-ледников на масляную кампанию 1911 г. и отправки масла по железной дороге, организации первой выставки маслоэкспортеров и деятелей по молочному хозяйству, выработка программы следующего съезда ${ }^{38}$.

Председателем был прочитан краткий обзор перевозки масла в 1910 г. Вывоз масла в кампанию составил 3195267 пудов (планировали 3828000 пудов) и был наиболее интенсивным с самого начала перевозок масла по Сибирской железной дороге ${ }^{39}$. Вывоз масла в 1910 г. распределился следующим образом.

Из таблицы 7 видно, что недовывоз против плана составил 95533 пудов (2,96\%) - по Омскому, Барнаульскому, Каинскому районам. В качестве основных причин данного явления назывались неблагоприятные условия для крестьянского хозяйства - холодная и дождливая погода, повальные болезни скота ${ }^{40}$. Объемы подвоза масла

\footnotetext{
37 Журналы заседаний Совещания маслоэкспортеров 22-23 января 1911 г. Омск, 1911. С. 2.

38 Там же.

39 Там же. С. 3.

40 Там же. С. 9.
}

в предшествующий год были подвержены более значительным колебаниям, чем ранее: в весенние месяцы наблюдалось превышение планируемого подвоза, а в осенние месяцы подвоз был ниже предположений: апрель $(+46,76 \%)$, май $(13,59 \%)$, август $(-12,67 \%)$, октябрь $(-16,19 \%)$.

Таблииа 7

Вывоз масла по районам в 1910 г.

\begin{tabular}{|l|c|c|}
\hline \multicolumn{1}{|c|}{ Район } & $\begin{array}{c}\text { Предполо- } \\
\text { жено к вы- } \\
\text { возу (пуд.) }\end{array}$ & $\begin{array}{c}\text { Вывезено } \\
\text { в действитель- } \\
\text { ности (пуд.) }\end{array}$ \\
\hline Курганский & 802800 & 818784 \\
\hline Петропавловский & 222100 & 254801 \\
\hline Омский & 905200 & 889366 \\
\hline Каинский & 162300 & 138498 \\
\hline Барнаульский & 1200400 & 1093818 \\
\hline
\end{tabular}

Источник: Журналы заседаний Съезда маслоэкспортеров 22-23 янв. 1911 г. Омск, 1911. С. 6.

Увеличение отправки масла по северному направлению (на 249740 пудов больше, чем в прошлом году) являлось, как отмечалось на съезде, не случайным, а объяснялось преимуществом, которое дает этот путь, - уменьшением расстояния перевозки ${ }^{41}$. На Съезде маслоделов и экспортеров, который состоялся в 1909 г., было предположено к вывозу 3828000 пудов, из этого количества 3392800 пудов намечалось вывезти в летнюю кампанию. Для вывоза планировалось выделить 148 поездов западного направления и 99 - северного направления.

Недовывоз масла дали районы: Омский $(-1,75 \%)$, Каинский $(-14,66)$, Барнаульский $(-8,88)$, а превышение: Курганский $(+1,99)$ и Петропавловский $(+14,72)^{42}$. Вывоз масла на восток в минувшую кампанию оказался ниже прошлогоднего и выразился в 20858 пудах против 24166 пудов предшествующего года. Главными пунктами назначения в этом направлении являлись Иркутск, Харбин и Владивосток.

По подсчету комиссии, для вывоза масла средняя нагрузка вагона определилась в 590 пудов, и вагонов-ледников соответственно требовалось 5581. Жалоб на недостаток набивки льдом вагонов-ледников не наблюдалось.

В кампанию 1910 г. каждый масляный поезд сопровождался, как и ранее, двумя проводниками, наблюдавшими за своевременным ходом поездов и исправным пополнением вагонов-ледников льдом.

\footnotetext{
41 Там же.

42 Там же. С. 10
} 


\section{Исторический журнал: научные исследования № 3 (21) • 2014}

DOI: $10.7256 / 2222-1972.2014 .3 .13770$

Съезд разработал основные положения для составления плана перевозки масла на 1911 г. В течение последних лет объемы масла, перевозимого из Сибири к портам Балтийского моря, стабилизировались, поэтому для определения заданий на год было предложено исходить из измерения среднего вывоза за последние три года ${ }^{43}$ : общее количество вывоза за год и за кампанию определяется по фактическому вывозу в 1910 г. и среднему проценту прироста за последние три года; вывоз по районам распределяется по среднему проценту практического вывоза за последние три года; таким же путем распределяется это общее количество для каждого района по отдельным станциям направления.

Отношение вывоза масла в кампанию 1911 г. по направлениям к общему вывозу такового определялось в следующей пропорции: по северному направлению $71,5 \%$, по западному направлению 28,5\%. Ежегодное процентное увеличение отправки масла за кампанию последних трех лет составляло: 1909 г. против 1908 г. - 4,93\%, 1910 г. против 1909 г. $-7,19 \%$, в среднем $-6,06 \%{ }^{44}$.

Заседание XV Юбилейного съезда маслоэкпортеров и деятелей по молочному и холодильному делу проходило в Омске 5-9 декабря 1913 г. На съезде присутствовали 74 человека ${ }^{45}$. В программу заседания входили следующие вопросы: итоги перевозки сливочного масла в 1913 г., разработка заданий на масляную кампанию 1914 г.; обсуждались также меры против рекламы, призывающей к фальсификации сливочного масла, выносились вопросы об устранении путаницы марок бочонков в отправляемых партиях масла, об улучшении условий выработки масла, о доставке в Бюро комиссии копий рапортов проводников масляных поездов ${ }^{46}$.

Вывоз масла в кампанию 1913 г. определился в 4058650 пудов ${ }^{47}$. В кампанию было вывезено на 397591 пудов $(10,9 \%)$ больше, чем в 1912 г., и на 729358 пудов $(21,9 \%)$ больше, чем в 1911 г. Кроме того, вывоз масла в данный год впервые значительно превысил предположения съезда маслоэкспортеров - вывезено больше планируемого на 181850 пудов $(4 \%)^{48}$.

\footnotetext{
43 Там же. С. 23.

44 Там же. С. 27.

45 Журналы заседаний XV Юбилейного съезда маслоэкспортеров и деятелей по молочному хозяйству и холодильному делу. Омск, 1914. С. 2.

46 Там же. С. 4.

47 Там же. С. 11.

48 Там же. С. 12.
}

В связи с этим различалось распределение вывоза по месяцам и районам. По месяцам значительный недовывоз против предположений наблюдался только в апреле $(-20,8 \%)$, остальные месяцы дали заметное превышение: май $(+13,9 \%)$, июнь $(+5,3 \%)$, июль $(+2,2 \%)$, август $(+5,1 \%)$, сентябрь $(+10,3 \%)$, октябрь $(+7,7 \%)$. Увеличение вывоза масла в кампанию 1913 г. составляло ${ }^{49}$ :

- северное направление: вывезено больше планируемого съездом на 70964 пуда $(2,6 \%)$, против кампании 1912 г. - на 28984 пуда $(11,4 \%)$ и на 953612 пудов $(50,7 \%)$ больше, чем в кампанию 1911 г.;

- западное направление: вывезено больше планируемого на 49447 пудов $(4,4 \%)$, против кампании 1912 г. - на 114378 пудов $(10,8 \%)$, но менее кампании 1911 г. на 276173 пудов (19,1\%).

На съезде в декабре 1912 г. было предположено к вывозу в 1913 г. 4805000 пудов сливочного масла, 82\% (3 940000 пудов) намечалось вывести в летнюю кампанию (апрель-октябрь) ${ }^{50}$. Для выполнения перевозки данного количества масла, считая среднюю нагрузку вагонов-ледников в 650 пудов, требовался состав поезда западного направления в 25 вагонов-ледников и северного направления - в 31 вагон-ледник. Действительный вывоз масла в кампанию 1913 г. по районам отражает табл. 8.

Таблииа 8

Вывоз масла по районам в кампанию 1913 г.

\begin{tabular}{|l|c|c|}
\hline \multicolumn{1}{|c|}{ Район } & Предположено & $\begin{array}{c}\text { Вывезено } \\
\text { в действитель- } \\
\text { ности }\end{array}$ \\
\hline Барнаульский & 1600893 & 1756025 \\
\hline Каинский & 238657 & 257568 \\
\hline Омский & 1114693 & 1164978 \\
\hline Петропавловский & 238657 & 222675 \\
\hline Курганский & 694500 & 657404 \\
\hline
\end{tabular}

Источник: Журналы заседаний Съезда маслоэкспортеров и деятелей по молочному хозяйству 5-9 дек. 1913 г. Омск, 1914. С. 14.

Как видно из таблицы 8, превышение против предположений дали Барнаульский, Каинский, Омский районы.

Всего за этот период (май-октябрь) агентами-проводниками было сопровождено 189 поездов (65 поездов западного направления, 124 поезда северного направления).

\footnotetext{
49 Там же.

50 Там же. С. 13.
} 


\section{Экономическая история, история предпринимательства}

При составлении плана вывоза масла на 1914 г. принимались во внимание постановления предыдущего съезда, прирост и убыль перевозки масла за последние три года ${ }^{51}$.

Сравнивая цифру этого задания с 1913 г., получаем превышение на 353300 пудов $(8,7 \%)^{52}$. Из-за отсутствия данных об общей годовой перевозке масла в 1913 г. процент вывоза масла в кампанию 1914 г. был принят по среднему вывозу за три года (1910-1912 гг.) Таким образом, за 1914 г. было предположено к вывозу 5458000 пудов. Означенное количество распределилось по районам: Барнаульский - 2538000 пудов, Каинский - 344000 пудов, Омский - 1490000 пудов, Петропавловский - 278000 пудов ${ }^{53}$.

На съезде обсуждался вопрос о мерах против рекламы, призывающей к фальсификации масла ${ }^{54}$. Случаи подобной рекламы в Омске были к этому моменту уже два раза. В 1911 г. фирма «Иоффе» предлагала кокосовое масло, специально приготовленное для подмешивания к сливочному маслу. В 1913 г. фирма «Граац» обращалась с подобным предложением к экспортным конторам и даже прислала образец своего продукта. При исследовании в лаборатории продукт оказался салом. Такие предложения могли проникнуть в деревню, и порча масла могла перейти на места производства. Данное явление было угрозой всей отрасли сельского хозяйства, т. к. могло подорвать репутацию продукта на заграничных рынках. Съезд постановил просить Министерство торговли принять меры к прекращению выпуска подобной рекламы и выработать соответственный законопроект о мерах борьбы с фальсификацией. Это интересный пример защиты корпоративных интересов сибирских маслоделов, отстаивания региональной репутации сибирских экспортеров.

Съезд рассмотрел вопрос об устройстве периодических выставок сливочного масла для проведения экспертизы, чтобы установить заводы, которые производят масло высокого качества ${ }^{55}$. Члены съезда сошлись на мнении, что значительное содействие улучшению качества масла будут оказывать специальные контрольные станции при существующих лабораториях, которые могут производить круглый год иссле-

\footnotetext{
51 Там же. С. 100.

52 Там же.

53 Там же. С. 59.

54 Там же. С. 115.

55 Там же. С. 115.
}

дования масла, поступающего на рынки. Съезд постановил устраивать районные выставки и конкурсы масла для определения наиболее успешного завода. Это решение также свидетельствует о стремлении съезда повысить репутацию сибирского масла.

По вопросу о доставке в Бюро комиссий копий рапортов проводников масляных поездов съезд постановил возобновить ходатайство об изменении формы рапортов, чтобы данные проводников давали более точную картину условий следования масла в пути ${ }^{56}$. Цель получения копий - точно знать, при каких условиях масло шло за границу, т. к. часто поступали жалобы, что масло приходит в плохом виде вследствие неблагоприятных условий перевозки. В существующих формах рапортов не было конкретных указаний на условия, при которых следовало масло.

Председатель на съезде доложил о состоянии маслоделия в целом: «Данная отрасль развивается из года в год, особенно в количественном отношении. Необходимо обратить внимание на качественную сторону, чтобы масло могло конкурировать на заграничных рынках, где лучше перевозочные средства и шире применены технические усовершенствования. Разность в цене между высшими и низшими сортами масла достигает 4-5 рублей»57. Была подчеркнута необходимость избавляться от низших сортов, стремиться к тому, чтобы качество продукта было равномерным, а для этого улучшать оборудование заводов, не скупиться на оплату опытных мастеров, следить за состоянием производственных зданий ${ }^{58}$.

В целом проведенный анализ показывает, что в течение полутора десятилетий, предшествующих Первой мировой войне, в Западной Сибири возник крупнейший в Российской империи район производства сливочного масла, который быстро прошел әволюцию организационных форм, повысивших конкурентоспособность сибирских маслоделов как на внутреннем рынке, так и на экспортных направлениях.

Автор выражает признательность проф. Л. И. Бородкину и Д. В. Анисимовой (исторический факультет МГУ имени М. В. Ломоносова) за полезные консультации в ходе проведения данного исследования.

\footnotetext{
56 Там же.

57 Там же. С. 9.

58 Там же.
} 


\section{Исторический журнал: научные исследования № 3 (21) • 2014}

DOI: $10.7256 / 2222-1972.2014 .3 .13770$

\section{Библиография:}

1. Алексеева В. К. Артельное маслоделие в Сибири // Вопросы истории социально-экономической и культурной жизни Сибири и Дальнего Востока. Выпуск 2. Новосибирск, 1968. С. 78-92.

2. Алексеева В. К. К вопросу о развитии маслодельческой кооперации в Сибири // Бахрушинские чтения 1971 г. Выпуск 7. Новосибирск, 1972. С. 77-84.

3. Алексеева В. К. Превращение маслоделия в ведущую отрасль сельского хозяйства Сибири в конце XIX - начале XX вв. // Бахрушинские чтения 1974 г. Новосибирск, 1974. С. 134-139.

4. Алексеева В. К. Торговля сибирским маслом накануне Первой мировой войны // Исторические аспекты экономического, культурного и социального развития Сибири. Часть 2. Новосибирск, 1978. С. 41-46.

5. Гутерц А. В. Николай Верещагин. На благо Отечества. Вологда, 2011.

6. Кулибина Н. В. Внешняя торговля маслом в связи с пересмотром торговых договоров. Петроград, 1915.

7. Мурашкинцев А. А. Кооперативное маслоделие в Западной Сибири. СПб., 1902.

8. Мурашкинцев А. А. О производстве и экспорте масла в Западной Сибири. СПб., 1902.

\section{References (transliterated):}

1. Alekseeva V. K. Artel'noe maslodelie v Sibiri // Voprosy istorii sotsial'no-ekonomicheskoi i kul'turnoi zhizni Sibiri i Dal'nego Vostoka. Vypusk 2. Novosibirsk, 1968. S. 78-92.

2. Alekseeva V. K. K voprosu o razvitii maslodel'cheskoi kooperatsii v Sibiri // Bakhrushinskie chteniya 1971 g. Vypusk 7. Novosibirsk, 1972. S. 77-84.

3. Alekseeva V. K. Prevrashchenie maslodeliya v vedushchuyu otrasl' sel'skogo khozyaistva Sibiri v kontse XIX - nachale XX vv. // Bakhrushinskie chteniya 1974 g. Novosibirsk, 1974. S. 134-139.

4. Alekseeva V. K. Torgovlya sibirskim maslom nakanune Pervoi mirovoi voiny // Istoricheskie aspekty ekonomicheskogo, kul'turnogo i sotsial'nogo razvitiya Sibiri. Chast' 2. Novosibirsk, 1978. S. 41-46.

5. Guterts A. V. Nikolai Vereshchagin. Na blago Otechestva. Vologda, 2011.

6. Kulibina N. V. Vneshnyaya torgovlya maslom v svyazi s peresmotrom torgovykh dogovorov. Petrograd, 1915.

7. Murashkintsev A. A. Kooperativnoe maslodelie v Zapadnoi Sibiri. SPb., 1902.

8. Murashkintsev A. A. 0 proizvodstve i eksporte masla v Zapadnoi Sibiri. SPb., 1902. 